\title{
CAPE CANAVERAL AND THE SPIRIT OF SCIENCE
}

$\mathrm{O}^{\mathrm{N}}$ N February 21, Colonel John Glenn circled the Earth three times in a space-vehicle and, about five hours later, landed safely at a pre-determined spot (see also p. 827 of this issue).

The congratulations of all should be extended to the United States, and especially to their brilliant scientists and technicians; but the personal bravery of Colonel Glenn must not be overlooked. As a scientist and as a man, Colonel Glenn now stands side-by-side with the Russians, Gagarin and Titov. The fact that the Russians were first in this field is of scant scientific importance-claims for priority in this, as in other scientific fields, add little or nothing to the advancement or dignity of science.

The American scientists and technicians, and by no means least Colonel Glenn himself, must at times have felt exasperated at what appeared to be interminable cancellations and delays-due to technical difficulties, meteorological conditions, etc. In the long run, this will count as nought, for from the first, at any rate to the scientists of the world, it was obvious that the Americans would eventually succeed.

Fundamentally, this feat is a further triumph for science. Colonel Glenn's achievement is, of course, of great significance; but even greater is the way the entire project was conceived, prepared and eventually successfully carried out. During the past months, indeed years, peoples of the world (mainly politicians and other laymen) have been heard to say: "Why cannot the Americans keep quiet until they actually have put a man into orbit and successfully retrieved him ?" This is quite a wrong attitude. In fact, the very policy of the United States is the one for which that country can be congratulated and thanked. They have adopted the real spirit of scientific endeavour. Freedom to carry out research is only part of the policy of science; freedom to publish one's results is equally as important. The United States has kept the world informed not only of her successes but also of her failures or set-backs. One learns from the latter as well as from the former; and science owes it to the world to be the universal teacher. It should never be the catspaw of nationalism.

We may be sure that Colonel Glenn has been the first American to orbit the Earth. On the other hand, the U.S.S.R. still persists in wrapping much of its scientific endeavour, especially in the fields of physics and engineering, in secrecy; so that country can have no cause for complaint about the rumours that Gagarin was not the first Russian to go into orbit, though no doubt he was the first to do so successfully. Nature has noticed this attitude over a very long period (long before space research had achieved the proportions that it enjoys to-day), and has made every endeavour to bring it home to our Russian colleagues that it is not in the interests of science to hide one's light under a bushel. Until the beginning of the Second World War Russia (and eventually the U.S.S.R.) did not hesitate to publish her scientific results in Nature-which aims at being an international journal recognizing no national boundaries. The most recent consequence of our endeavours to rectify matters has been an assurance from one of the leading present-day Russian scientists that they are prepared to publish scientific discoveries in the "natural history" of their country. There is no need to stress the significance of this decision.

Therefore, although the fact that Colonel Glenn and the scientists and technicians behind him have at last succeeded in their endeavours will bring satisfaction and pleasure in most parts of the world, of greater significance, especially to the scientists, is the fact that the Americans insisted and persisted in publicizing their endeavours in this branch of science from the very beginning-not just when success was being and had been achieved.

In the long run, and while history is being made, truth cannot be suppressed. Priority does not necessarily bring prestige. All that basically matters is that scientific discovery, no matter when or by whom, should add to the advancement of science and of mankind. One British newspaper on the day following this American achievement banner-headlined its feature article thus: "But I say 5-1 against an American first on the Moon". Perhaps the time will come when the lay Press and laymen recognize that our scientific and technical laboratories are not race tracks.

It has been said that "the Americans are spreading their money and manpower to advance along a broad front into space". That is just as it should be, for in that, and only that, way can the world hope to reap rich rewards and benefits. On the other hand, now having already orbited the Earth, the Russians seem to be concentrating on reaching the Moon, mainly because of its tremendous prestige possibilities. If being the first on the Moon really gives prestige to any one country, that reflects sadly on the general appreciation of science, and cannot, in the long run, add to its advancement. Political prestige should have no part in scientific endeavour; what is badly needed is comprehensive world collaboration in scientific research, not only to avoid duplication of effort (and thus save much of the public's funds), but also to ensure that science is carrying out its true function-addition to knowledge-and, in its own peculiar way, contributing to man's never-ending attempt at revelation of the truth. Offors and promises concerning closer international collaboration periodically made by leading statesmen will bring greater satisfaction to the scientists when there are more tangible signs of such promises being imple. monted. 